\title{
"Liberty of the Compiler": Catalogue Raisonné as Metaphor for Collaborative Design
}

\author{
Adam Lauder
}

The IAINBAXTEREraisonnE creatively repurposes the conventions of print catalogues raisonnés to support the development of an experimental scholarly communications platform and collaborative e-research zone. The IBEraisonnE responds to a growing literature on digital humanities that addresses the unique requirements of humanities scholars in an e-research environment. The open-ended and critical approach to the catalog and collection adopted by the IBEraisonnE is inspired, in part, by examples of premodern catalogs by Pierre-Jean Mariette (1694-1774) and Edme-François Gersaint (1694-1750). This paper describes some of the applications to which eighteenth-century compilation practices have been adapted and put to new use by IBEraisonnE developers.

[The following article is an expansion of a paper presented at the "Case Studies III" session at the VRA + ARLIS/NA Joint Conference held in Minneapolis, Minnesota, in March 2011.]

\section{Introduction}

The prototype IAINBAXTEREraisonnE $E^{1}$ is an experimental project hosted by York University Libraries that seeks to expand and transform the traditional catalogue raisonné format into a dynamic electronic collection, collaborative scholarly communications platform, and discovery zone (Figure 1). Project developers bring a range of humanities backgrounds to bear on the IBEraisonnE. Capitalizing on the unique opportunity represented by York's W.P. Scott Chair for Research in e-Librarianship - a rotating appointment designed to support innovation within the library profession-developers made an early decision to harness their humanities subject expertise to explore

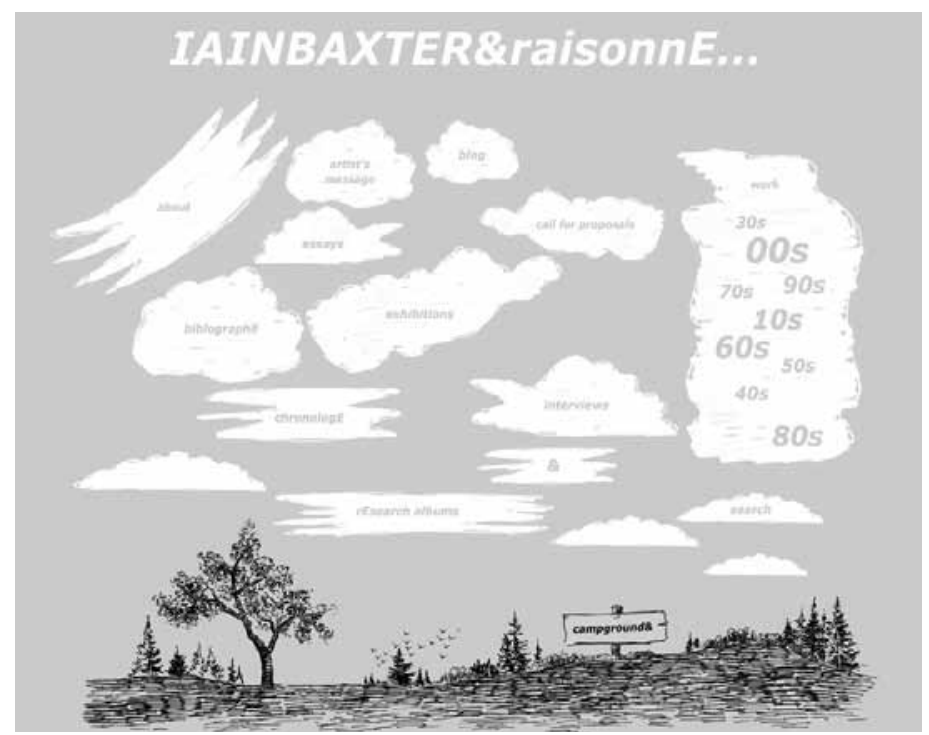

Figure 1. Victor Romão. IAINBAXTER\&raisonnE Landing Page. 2010. Courtesy Victor Romão and IBEraisonnE. http:/ / archives.library.yorku. ca/iain_baxterand_raisonne/ critical approaches to the emerging field of digital humanities. The project is being developed in collaboration with Canadian conceptual artist IAIN BAXTER\& and in partnership with an international and interdisciplinary team of scholars as well as the Art Gallery of Ontario and the Centre for Contemporary Canadian Art. The IBEraisonnE breaks with the linear, hierarchical, and static structures of traditional catalogues raisonnés

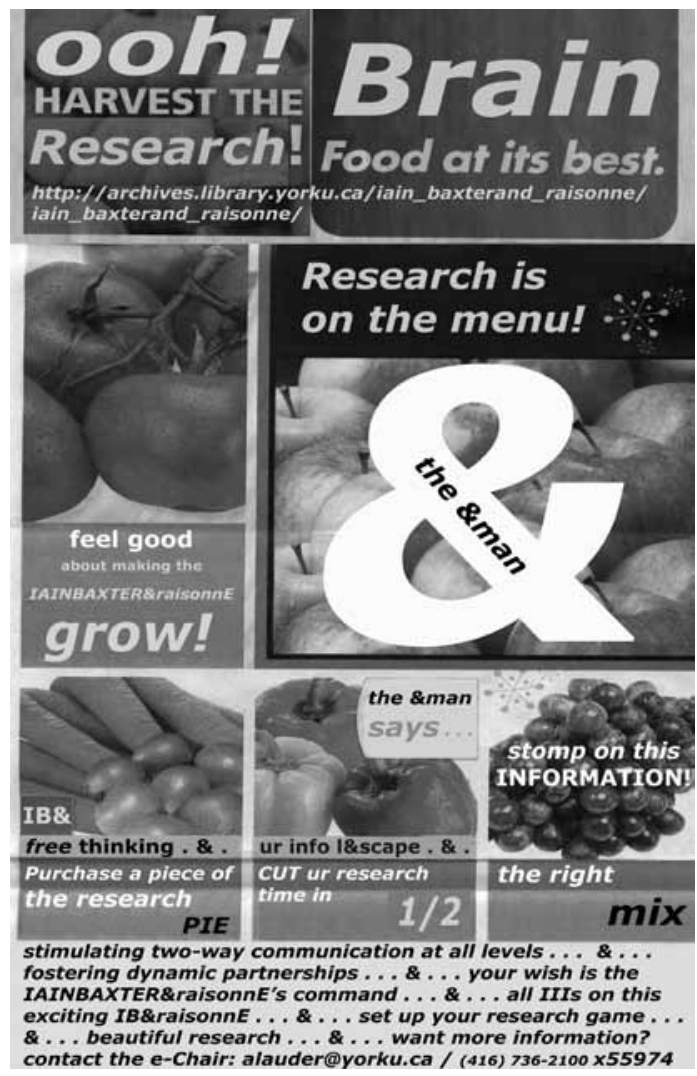

Figure 2. IAIN BAXTERE and Adam Lauder. IB\&raisonnE Research Recruitment Poster. 2010. Courtesy IAIN BAXTERE and Adam Lauder. http://archives.library.yorku.ca/iain_baxterand_raisonne/archive/fullsize/ food_for_thought_75ed5a1848.jpg 
by adding content in direct response to the evolving creative, research, and teaching needs of a diverse constituency of artists, scholars, and students currently researching IAIN BAXTER\& (Figure 2).

The collaborative design of the IBEraisonnE is informed by an ongoing investigation of the historical development of catalogues raisonnés. The open-ended and critical approach to the catalog and collection adopted by the IBEraisonnE is inspired, in part, by examples of pre-modern catalogs by Pierre-Jean Mariette (1694-1774) and Edme-François Gersaint (1694-1750) in addition to the flexible and flat information infrastructure of the N.E. Thing Co. Ltd. (1966-1978), the conceptual art project and legally-incorporated business founded by IAIN BAXTER\& in 1966 and administered with his then wife Ingrid Baxter until 1978. The approach adopted by the IBEraisonnE was hinted at by Jonathan Franklin in an earlier article published in the pages of this journal. ${ }^{2}$ This paper describes some of the applications to which compilation practices that served as the condition of possibility for the emergence of eighteenth-century catalogues raisonnés have been adapted by IBEraisonnE developers to meet fresh challenges in the field of digital humanities.

Born Iain Baxter in Middlesbrough, England, in 1936, BAXTER\& (Figure 3) moved to Canada with his family in 1937. He earned degrees in zoology and education at the University of Idaho prior to receiving his MFA at Washington State University in 1964. Scholar Isabelle Hermann has persuasively argued that this multidisciplinary schooling informed the artist's quasiscientific methodology. ${ }^{3}$ In particular, his training in zoology may have stimulated his life-long interest in exploring and exploding classifications - an investigation to which the experimental structure of the IBEraisonnE responds. In 1961, the artist spent a year in Japan subsidized by a government scholarship. This sojourn strengthened the importance of Zen to the artist's practice. ${ }^{4}$ As an assistant professor at the University of British Columbia, BAXTER\& helped to organize the 1965 Marshall McLuhanthemed Festival of the Contemporary Arts. ${ }^{5}$ This early exposure to the ideas of the Canadian media guru had an immediate and lasting impact on the artist's production, ${ }^{6}$ which rapidly shifted from hard-edge abstract painting to works inspired by popular culture: inflatable plastic landscapes that recycled the romantic

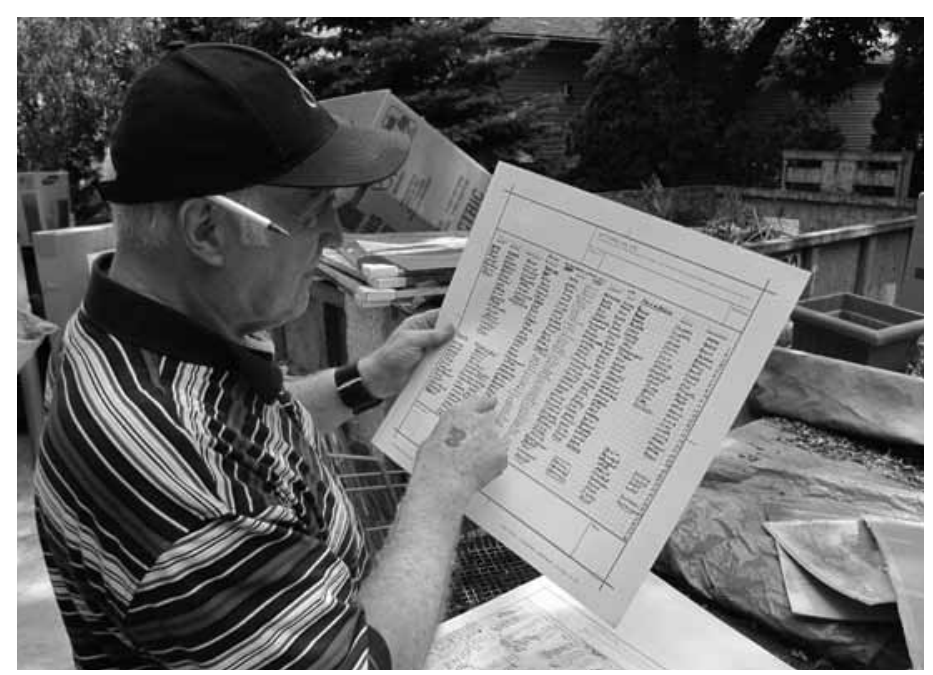

Figure 3. Adam Lauder. IAIN BAXTER\&. 2010. Courtesy Adam Lauder. territory mined by the Group of Seven into objects resembling pool toys. $^{7}$

Beginning in 1966, under the corporate umbrella of the conceptual art project N.E. Thing Co., BAXTER\& shifted his production from a manufacturing base to a post-studio practice that registered broader transformations in the North American economy under the impact of computerization. ${ }^{8}$ In keeping with these developments, the stock-in-trade of the N.E. Thing Co. was "Sensitivity Information," an idiosyncratic code which translated the actions of Company personnel into formulas recalling the mathematical figures deployed by information theorists such as Abraham Moles. BAXTER\&'s significant innovations during the fertile period of the late 1960s-which included completely dematerialized and "networked" telex and telecopier workshave received acknowledgement from such notoriously critical historians of the period as Lucy Lippard ${ }^{9}$ and Joseph Kosuth. ${ }^{10}$

Since 1978, BAXTER\&'s practice has continued to investigate concepts drawn from information theory-most notably the Boolean connector "and," which the artist legally affixed to his name as an ampersand in 2005. However, ecological and environmental themes have come to dominate his practice in recent decades. Since retiring from the School of Visual Arts at the University of Windsor in 2002, BAXTER\& has also continued to develop innovative pedagogical strategies-exemplified by the ECOARTVAN (2010) ${ }^{11}$ _of which the IBEraisonnE can be seen to be the latest development in a line dating back to the artist's studies in education and subsequent experiments in non-verbal teaching. ${ }^{12}$ The primary challenge faced by developers of the IBEraisonnE has been to design a container sufficiently plastic to "bag" the contents of the prolific and incessantly creative career sketched above. In keeping with the artist's ongoing adaptation of classification conventions as well as the spirit of play which informs that engagement, the IBEraisonnE has proceeded through an innovative investigation of historical practices of cataloging and classification as well as a case study of the artist's personal information management ${ }^{13}$ behaviors and the visionary representations of information found in his work. These diverse approaches are united by a common digital humanities framework tempered by tactics drawn from critical information studies.

\section{A Brief History of Catalogues Raisonnés}

A brief history of the earliest catalogues raisonnés sets the stage for the critical approach to participatory design discussed below. Art historian and curator Graham Larkin, in his 2003 dissertation on printmaker Jacques Callot, produced a provocative study of the earliest catalogue raisonné devoted to an artist. ${ }^{14}$ Compiled by the Parisian art dealer Gersaint, the catalogue raisonné of Callot was issued as part of a 1744 sales catalog published on the occasion of the estate sale of collector Quentin de Lorangère: Catalogue raisonné des diverses curiosités du cabinet de feu M. Quentin de Lorangère..$^{15}$ Larkin argues that the practices of compilation and publication marshaled by Gersaint promoted a containment of the works of Callot as they (co-)existed at that time in the albums of collectors such as Lorangère. Prior to the emergence of the catalogue raisonné, it was possible to speak of multiple oeuvres when discussing the work of an artist. Oeuvre denoted a particular compilation or recueil. ${ }^{16}$ Authorship took second place in such compilations, which were content- 
driven. ${ }^{17}$ As in Alison McQueen's study ${ }^{18}$ of the transformation of Rembrandt's biography into romantic myth, Larkin argues that the catalogue raisonné was instrumental in the emergence of the modern concept of an oeuvre and of associated notions of authorship and artist biography. Larkin's study re-focuses attention onto the author function of compilers as well as the "network of publishers, dealers and amateurs" which sustained that compilation activity. ${ }^{19}$ He goes so far as to suggest that, "even if we were to . . . focus solely on Callot, and ascribe all oeuvre-making to him, it would be wrong to construe his artistic production as somehow prior to, or separate from, practices of interpretation and compilation. ${ }^{20}$ Larkin is suggesting that, in a sense, the printmaker "compiled" his own oeuvre in parallel with the compilation practices of collectors.

Gersaint's catalogs are relevant to the present study less for their contribution to the emergence of the modern art historical methodologies noted by Jonathan Franklin, than for their retention of the participatory features of albums produced by gentleman compilers of the pre-modern era. Larkin dubs that compilation activity ars combinatoria and likens it to the cinematic technique of montage. ${ }^{21}$ The ars combinatoria described by Larkin resembles the behaviors of social media users today, and therefore has much to teach contemporary knowledgemanagement professionals about facilitating user participation in processes of knowledge organization and dissemination.

The distinctive contours of amateur compilation as an approach to classification emerge clearly from the introduction to the Lorangère catalogue raisonné, in which Gersaint wrote: "There is nothing fixed about the arrangement that we have given to the prints; we have the liberty of using them in the manner which seems most useful and agreeable or according to the genre which we embrace ( my translation)."22 Larkin underlines "Gersaint's respect for personalization." 23 This respect is embodied by the dealer's own comments: "I decided to arrange each portfolio [of prints] in the state in which I found it, without addition or omission, simply dividing the collection into lots; I made the catalog subsequently, after the lots were thus arranged (my translation)." ${ }^{24}$ Franklin notes that this respect for original order was unique to the French context, "British catalogs . . . being more interested in order for the purposes of sale than for intellectual gratification." 25 The ideals of order preserved by Gersaint were, by contrast, tied to the mechanics of album compilation executed by amateurs or, in rare cases, supervised by experts such as Mariette. The behaviors of users determined Gersaint's approach to organization. Moreover, the structure of the compilations upon which his catalogs were based was often aesthetically motivated and reflected the values of connoisseurship cultivated by the amateur collectors who constituted his market.

Larkin proposes that the topical ideals of order manifested in early eighteenth-century compilations (upon which the catalogs of Gersaint were based) reflect a "structuring propensity which runs deeper in the collective unconscious than any ... intellectualized policy statement" such as a library scheme." ${ }^{26}$ "[O]rdering or ranking," Larkin insists, is "a visual affair." 27 He compares the structuring activity legible in the visual order of early catalogues raisonnés to the concept of habitus developed in the writings of French sociologist Pierre Bourdieu. Larkin's Bourdieuian approach is compatible with Lisa Hussey's recent applica- tion of Bourdieu's methodology to contemporary problems in library and information science. ${ }^{28}$ The habitual dispositions of compilers are preserved today in the jewel-like arrangement of prints on single pages of some albums as well as in the way that some prints have been cut or folded, offering evidence that the "formal properties of prints exert[ed] their own pressure on the compiler, leading to configurations which go against the logic of subject categories." 29 The purely decorative or associative logic of such interventions echoes the "innate disorder" of the artist's own practice, ${ }^{30}$ who proposes that Callot's inclusion of "interthematic visual puns . . . encourage[d] the compiler to actively participate in the interference with the usual subject arrangement" (my emphasis). ${ }^{31}$ While cautioning against a celebration of disorderly compilation, Larkin's study emphasizes the constitutive role of user participation in scholarly practices of collecting, compilation, and commercial/scientific dialogue and exchange.

Franklin also identifies a distinct logic at work in the Callot catalogue raisonné published as part of Gersaint's Lorangère catalogue raisonné, whose amateur-driven components physically contained it. Rather than representing the contents and original order of a single collection, Gersaint's Callot catalogue raisonné "combined the guiding principle of listing the works of a single artist with the idea of covering more than one collection, thus inaugurating the 'catalogue raisonné' as we know it today." ${ }^{\prime 2}$ Nevertheless, Larkin's study shows that the modern format of the catalogue raisonné was born into a world of amateurs, whose consumption habits and personal information management practices defined the context of its circulation and reuse. Mariette's hand-written catalogs underline that even in cases where early catalogues raisonnés were supervised by experts, they tended to retain a degree of personalization and heuristic organization that disappeared in the nineteenth century.

\section{The Politics of Participation}

Larkin's focus on the user as a producer of scholarly norms and media practices is symptomatic of a recent trend in historical studies of reference formats that redefines the reader as a prosumer, ${ }^{33}$ whose information behaviors contribute to the scholarly negotiation of textual meanings. For instance, M.D. Eddy's article on the Philosophia Botanica of Carl Linnaeus (1707-1778) reveals that even the celebrated taxonomy of the Swedish scientist was as much a product of contemporaneous workflows as of scientific observation. ${ }^{34}$ Eddy argues that the organization of Linnaeus's text mirrored the structure of cabinets developed to facilitate laboratory workflows. Such workflows were, in turn, based on mnemonic practices of commonplacing-a form of information management that functioned as a personal memory aid-much like a modern scrapbook-by organizing content spatially by topics or themes unique to the interests of the compiler. ${ }^{35}$ Like the catalogs of Gersaint, commonplacing privileged "the liberty of the compiler" 36 and offered a flexible framework that could be "respatialized on a case-by-case basis." ${ }^{\prime 37}$ However, this user-centered framework was rendered invisible to subsequent generations of readers once Linnaean tables were decontextualized through transfer to print.

The vision of an "adjustable archive of nature" 38 which emerges from Eddy's study of eighteenth-century scientific technologies suggests analogies with contemporary social software. A similar picture of early reference formats is visible in Dániel 
Margócsy's study of pre-Linnaean encyclopedias. ${ }^{39}$ According to Margócsy, the encyclopedia format was a product of practices of "long-distance exchange" between scholars that-like the subsequent catalogs of Gersaint-embodied a commercial logic of circulation. ${ }^{40}$ Like the encyclopedias studied by Margócsy, Gersaint's catalogs constituted "mobile and lasting repositories of information" at the service of a network that included amateurs, dealers and specialists who repurposed those repositories as information behaviors evolved. ${ }^{41}$ Likewise recalling Gersaint, some early encyclopedias (marketed to connoisseurs as opposed to scholars) reveal a purely visual approach to taxonomization. Such texts were often transformed by readers according to personal preference, thereby endowing them with the status of "social manuscript[s]." ${ }^{42}$ Margócsy's study-which includes significant commentary on seventeenth- and eighteenth-century "conchologies" (catalogs of rare seashells), ${ }^{43}$ in which Gersaint also specialized ${ }^{44}$ - paints a picture of the broader (commercial and scientific) contexts of user participation in which the catalogues raisonnés studied by Franklin and Larkin developed. The circulation of commodities-paintings and seashells alike-gave shape to habits of classification in tandem with the connoisseurial tastes of collectors.

Franklin notes that the catalogues raisonnés of Gersaint coincided with the inauguration of more systematic approaches to reference formats which are common today. Even so, amateur compilation practices consistent with the participatory logic of pre-modern commercial and scientific catalog production and circulation thrived well into the nineteenth century. The information behaviors of users were also prioritized in the nineteenth-century photographic albums studied by Martha Langford. For Langford, "[T] here is no generic compiler," 45 since album arrangement was intended to "reactivat[e] a suspended conversation" 46 which was unique to the author of the compilation. The organizational logic of these private albums is mnemonic and oral, "based on imaginal dialogues, on the lost scripts of presentation ${ }^{\prime \prime 7}$ which would have been recited by their compilers during participatory performances.

The participatory nature of early reference formats revealed by the materialist reading of the social contexts of their emergence suggests parallels between pre-modern publication patterns and contemporary approaches to digital humanities, e-learning, and e-research. Participation figures prominently in a growing literature on learning which explores the supposedly unique behaviors of Millennials, or "the Google generation,"48 and celebrates the purportedly inherent interactivity of new media. Yet, the editors of a recent anthology which places contemporary social media within a historical continuum of participatory sociotechnical arrangements caution that current discourse is "all too often obscured by a 'rhetoric of newness' that assumes participatory media is radical and revolutionary, something unique in history." ${ }^{49}$ The rhetoric of newness identified by Ekström, Jülich, Lundgren, and Wisselgren is exploited by special interests which urge the adoption of social media to further goals of commercialization. "[D]iscussions about today's new media have somewhat undertheorized the politics of participation. . . . [T] here are certain affinities in the ways that research, business, education, and government policy conventionally refer to the empowering possibilities of new media. In some of these discussions, there is a tendency to neglect the asymmetries of participation." ${ }^{150}$ The recent public relations text SocialCorp is exemplary of a recent spate of titles whose relentless boosterism of social media in business contexts bears an uncanny resemblance to the uncritical rhetoric of participation espoused by some practitioners and theorists of library and information science. ${ }^{51}$ We sometimes appear to be returning to the era of the eighteenth-century amateur in more sense than one: participation is all too often tied to a renewed commodification of knowledge and knowledge organization. The mobile device is the new conch.

In brief, History of Participatory Media: Politics and Publics, 1750-2000 urges that contemporary designers of information technologies learn from history's mistakes and move beyond ahistorical dichotomies between active and passive audiences and medium-specific criteria of interactivity. In her contribution to History of Participatory Media, Lisa Gitelman insists that "participatory media [...] is always more a question of who participates and what forms participation may take than it is a question of technology" (my emphasis). ${ }^{52}$ In his contribution to the same anthology, Bodil Axelsson examines the politics of participation associated with online museum collections. Axelsson warns that in some cases media touted as participatory may actually cultivate forms of "interpassivity," a term which he borrows from critical theorist Slavoj Zizek to denote the condition fostered by media which limits user choice to a pre-defined and predictable set of outcomes. ${ }^{53}$

\section{IB\&raisonnE}

A similar critical and historical approach to that promoted by History of Participatory Media was adopted by the IBEraisonnE from the earliest phases of project development in revisiting the social dimension of the first catalogues raisonnés. A literature review confirmed Franklin and Larkin's analyses of the formative character of social context in the development of early catalogues raisonnés. Like Franklin and Larkin, Andrew McClellan places the catalogs of Gersaint squarely within the commercial milieu of eighteenth-century marchands mercier - whom Diderot derisively defined as "makers of nothing and sellers of all" - and their elite clientele of amateurs. ${ }^{54}$ Viewed through this lens, the catalogue raisonné emerges as both a marketing tool and a model of genuinely interactive and responsive scholarly communication. On one hand, unearthing this hybrid identity of the catalogue raisonné format draws attention to the political tensions inherent in the work of IAIN BAXTER\&, an artist who formerly operated as a legally-incorporated business and who routinely appropriates commercial objects into his current practice in order to critique, but also as a means of participating within, the contemporary marketplace. On the other hand, this recognition serves as a constant reminder to developers to avoid the exclusionary practices which supported the elite network of amateurs to which the emergence of the earliest catalogues raisonnés responded as well as the limiting practices conducive of interpassivity studied by contributors to History of Participatory Media. The IBEraisonnE seeks to respond to the expressed needs of scholars and other users without thereby succumbing to the endless stream of cognitive science-inflected studies of information seeking based on what David M. Nichols and others have termed "single user stereotypes." 55 Such one-dimensional models have been thrown into crisis by recent publications such as the anthology Critical Theory for Library and Information Science, whose editors urge that 
"a critical framework allows us to see how information seeking is part of a larger milieu that has many social dimensions in play." The social context of contemporary information technologies has been at the forefront of IBEraisonnE development from the start.

Reactivating Gersaint's respect for personalization, technical components of the open-source Omeka platform which currently houses the IBEraisonnE have been repurposed to accommodate the needs of contributors and users as expressed through a dialogical ${ }^{57}$ cycle of e-mail, telephone conversations, and face-to-face meetings. In responding to user feedback and needs in this way, project developers have applied the iterative principles of Actor Network Theory ${ }^{58}$ and Soft Systems ${ }^{59}$ methodology. For example, a page of dynamic links to the artist's favorite websites was created by artist and illustrator Victor Romão in the form of a "campground," as conceived in dialogue with BAXTER\& (Figure 4). In collaboration with BAXTER\& and the author, Romão is also in the process of creating a digital graphic novel, Eman $\mathcal{E}$ e-Chair (Figures 5-6), which recounts the origin and development of the IBEraisonnE that likewise sits within Omeka. Finally, Martha Langford's study of the psychodynamics of orality that informed nineteenth-century private photographic albums has provided a historical and theoretical framework for the IBEraisonnE's "rEsearch albums," intended to host "e-phemeral" online exhibitions ${ }^{60}$ and other dynamic, usergenerated interventions and content.

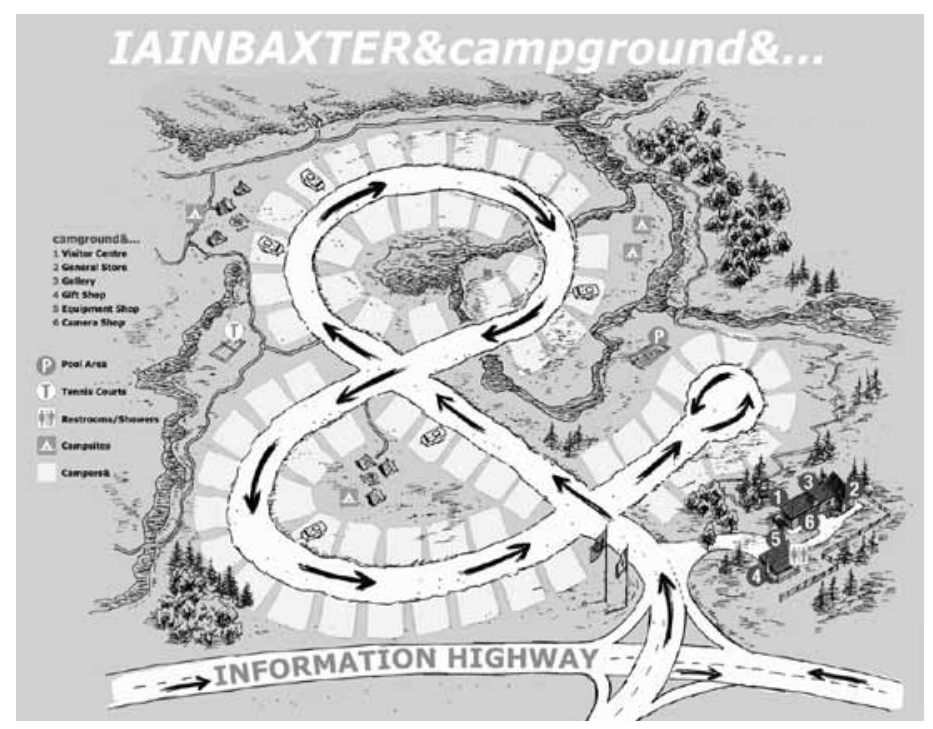

Figure 4. Victor Romão. IAINBAXTER\&RaisonnE_Campground\&. 2010. Courtesy Victor Romão and IBEraisonnE. http:/ /archives.library. yorku.ca/iain_baxterand_raisonne/campgroundand

Above all, the IBEraisonnE recalls Gersaint's respect for original order and the "liberty of the compiler" 60 through its application of a case study framework ${ }^{61}$ to modeling the personal information management behaviors of IAIN BAXTER\&. In addition, it undertakes an innovative historical study of the artist's visionary adaptation of information theory in his art practice since the mid-1960s. The flat structure of the IBEraisonnE's metadata reflects both the artist's personal tendency to "pile"62 information as well as his artistic conceptualization of information systems as a "portfolio" of piles. ${ }^{63}$ Throughout this process of study the artist is involved in project development as both
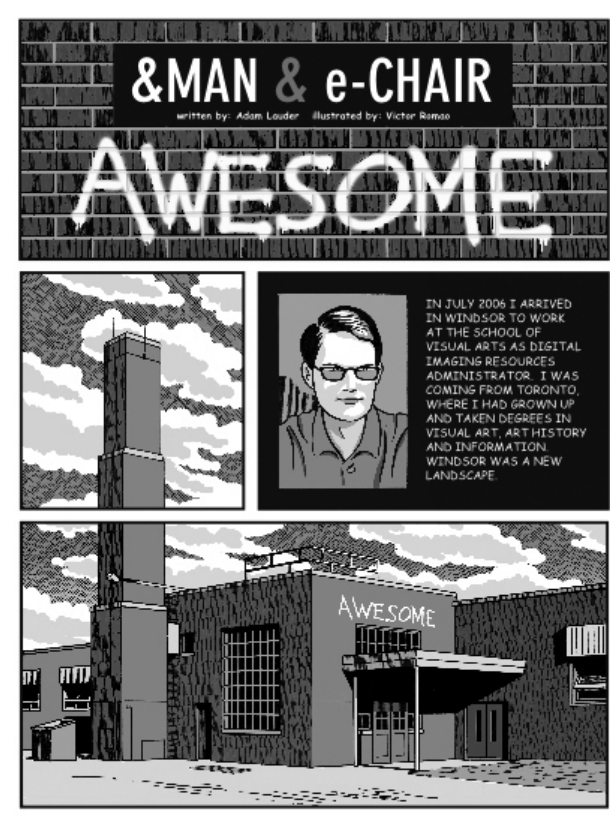

Figure 5. Victor Romão, Adam Lauder, and IAIN BAXTERE. \&man \& e-Chair. 2010. Courtesy Victor Romão and IBEraisonnE. http://archives. library.yorku.ca/iain_baxterand_raisonne/items/show/426

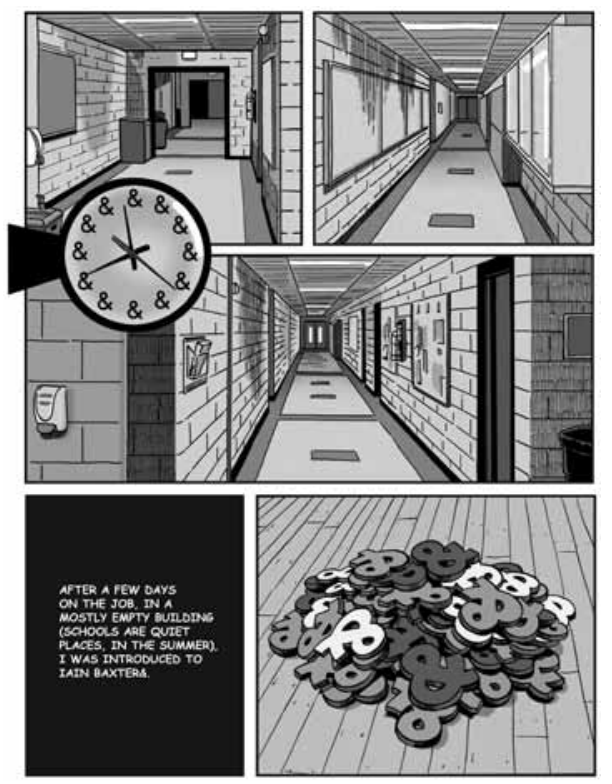

6. Victor Romão, Adam Lauder, and IAIN BAXTERE. \&man \& e-Chair. 2011. Courtesy Victor Romão and IBEraisonnE. http:/ /archives.library. yorku.ca/iain_baxterand_raisonne/items/show/1797

collaborator and research subject-contributing both practical and creative insights through continuous cycles of dialogue with other developers. The ambition of the IBEraisonnE is to make user participation as easy as it was for collectors to reconfigure the compilations upon which the earliest catalogues raisonnés were based by cutting and folding.

\section{Conclusion}

The IBEraisonnE responds to a growing literature on digital humanities that addresses the unique requirements of humani- 
ties scholars in an e-research environment-their desire to shape and re-shape evidence according to qualitative criteria. ${ }^{64}$ Project developers seek to address the documented lag in adoption of digital tools by humanities scholars by undertaking case studies of the personal information management behaviors and needs of individual humanities practitioners and researchers (notably IAIN BAXTER\& himself) and, above all, through ongoing exchange with users. This approach parallels and draws upon the insights of the Virtual Knowledge Studio (VKS), ${ }^{65}$ an experimental program designed to integrate the infrastructure and techniques of e-science into the humanities while retaining a critical objectivity and sensitivity to discipline-specific expectations and norms. The IBEraisonnE answers calls from Anne Beaulieu and Paul Wouters for more opportunities to engage in "experiment and play with new forms of research" 166 as well as Gary P. Radford's invitation to develop creative and imaginative approaches to library and information science. ${ }^{67}$ A combination of creative adaptability and sober self-reflexivity are essential to the success of such an open-ended program, which would not be feasible without the generous support of York University Libraries. York's dedication to supporting innovation through its endowed W.P. Scott Chair for Research in e-Librarianship has made this research possible. The generosity, creativity, and insights of IAIN BAXTER\& have also been essential at every stage. Finally, this speculative dialogue with the amateur compilers of the eighteenth century would have been meaningless without the concrete interaction of my collaborators, who form a collegial network that would have been the envy of any amateur or specialist of the eighteenth century.

\section{Notes}

1. Adam Lauder, IAIN BAXTER\&, Louise Chance Baxter, Rose Marie Barrientos, Vincent Bonin, Christophe Domino, Dennis Durham, and Isabelle Hermann, eds., IAINBAXTEREraisonnE, http:/ / archives.library.yorku.ca/ iain_baxterand_raisonne/.

2. "In Crozat's Recueil ... a kind of virtual catalog was born." Jonathan Franklin, "From Inventory to Virtual Catalog: Notes on the "Catalogue raisonné," Art Documentation 22, no. 1 (2003): 43. See also the discussion of Mariette's "Recueil Crozat" in Benedict Leca, "An Art Book and Its Viewers: The 'Recueil Crozat' and the Uses of Reproductive Engraving," EighteenthCentury Studies 38, no.4 (2005): 623-49.

3. Isabelle Hermann, "IAIN BAXTER\&: Pionnier et premier critique du photoconceptualisme 1967-1969," http:/ / archives. library.yorku.ca/iain_baxterand_raisonne/archive/files / hermann_iainbaxterand_pionnier_rev_3d95caf07e.pdf .

4. Derek Knight, N.E. Thing Co.: The Ubiquitous Concept (Oakville, ON: Oakville Galleries, 1995), 7.

5. Ibid., 10.

6. Ibid., 7 .

7. See Marie L. Fleming, Baxter ${ }^{2}$ : Any Choice Works (Toronto: Art Gallery of Ontario, 1982); Nancy Shaw, "Siting the Banal: The Expanded Landscapes of the N.E. Thing Co," in You Are Now in the Middle of a N.E. Thing Co. Landscape: Works by Iain and Ingrid Baxter, 1965-1971, eds. Nancy Shaw, Scott Watson, and William Wood (Vancouver: Fine Arts Gallery, University of British Columbia, 1993), 25-35; William Wood, "Capital and Subsidiary: The N.E. Thing Co. and the Revision of Conceptual
Art," in You Are Now in the Middle of a N.E. Thing Co. Landscape, 11-23.

8. See Eve Meltzer, "The Dream of the Information World," Oxford Art Journal 29, no. 1 (March 2006): 115-35.

9. Lucy R. Lippard, Six Years:The Dematerialization of the Art Object from 1966 to 1972 (Berkeley: University of California Press, 1997).

10. Joseph Kosuth, "Art After Philosophy," in Art After Philosophy and After, ed. Gabriele Guercio (Cambridge, MA: MIT Press, 1991), 28.

11. No. 9 Contemporary Art \& the Environment, "IAIN BAXTER\&: IAIN BAXTER\& ECOARTVAN," http:/ /www.no9. ca/exhibitions/IainBaxter/IainBaxter\&.html.

12. N.E. Thing Co. Ltd., N.E. Thing Co. Ltd., Vol. 1, http:// archives.library.yorku.ca/iain_baxterand_raisonne/archive/ files/nethingcovol1_comp_218e94dcf9.pdf.

13. For a discussion of personal information management as an information behavior and methodology, see Madirakshi Das and Alexander C. Loui, "Event Classification in Personal Image Collections," in ICME 2009 (New York: IEEE, 2009), 1660-63; Amber L. Cushing, "Highlighting the Archives Perspective in the Personal Digital Archiving Discussion," Library Hi Tech 28, no. 2 (2010): 301-12; Janet Finlay, John Gray, and Dawn Wood, "Integrating Repository Function with Work Practice: Tools to Facilitate Personal E-Administration," http:/ / www.jisc.ac.uk/media/documents/programmes / usersandinnovation/streamline\%20final\%20report.pdf; Catherine C. Marshall, "Rethinking Personal Digital Archiving, Part 1," D-Lib Magazine 14, no. 3/4 (March/April 2008), http:/ / www.dlib.org/dlib/march08/marshall/ /03marshall-pt2. html; Pete Williams, Katrina Dean, Iain Rowlands, and Jeremy Leighton John, "Digital Lives: Report of Interviews with the Creators of Personal Digital Collections," Ariadne no. 55 (April 2008), http:/ / www.ariadne.ac.uk/issue55/williams-et-al/.

14. Benjamin Graham Larkin, "The Elusive Oeuvre of Jacques Callot" (PhD diss., Harvard University, 2003).

15. Edme François Gersaint, Catalogue raisonné des diverses curiosités du cabinet de feu M. Quentin de Lorangère (Paris: Barois, 1744).

16. Larkin, "The Elusive Oeuvre of Jacques Callot," 54, 65. 17. Ibid., 68.

18. Alison McQueen, "Reinventing the Biography, Creating the Myth: Rembrandt in Nineteenth-Century France," Simiolus 28, no. 3 (2000-2001): 163-80.

19. Ibid., 26.

20. Ibid., 14 .

21. Ibid., 85, 102.

22. Gersaint, Catalogue raisonné, 46.

23. Larkin, "The Elusive Oeuvre of Jacques Callot," 86.

24. Gersaint, Catalogue raisonné, xi.

25. Franklin, "From Inventory to Virtual Catalog," 43.

26. Larkin, "The Elusive Oeuvre of Jacques Callot," 97.

27. Ibid., 98 .

28. Hussey's Bourdieuian approach to library and information echoes Larkin's focus on user behaviors and suggests other possibilities for applying critical sociological frameworks to problems in library and information science. Lisa Hussey, "Social Capital, Symbolic Violence, and Fields of Cultural Production," in Critical Theory for Library and 
Information Science, eds. Gloria J. Leckie, Lisa M. Given, and John E. Buschman (Santa Barbara, CA: Libraries Unlimited, 2010), 41-52.

29. Larkin, "The Elusive Oeuvre of Jacques Callot," 127.

30. Ibid.

31. Ibid., 128.

32. Franklin, "From Inventory to Virtual Catalog," 44.

33. Alvin Toffler's term, coined in 1980, may not be new, but its resonance in the library community is a new development. Alvin Toffler, The Third Wave (New York: Morrow, 1980).

34. M.D. Eddy, "Tools for Reordering: Commonplacing and the Space of Words in Linnaeus's Philosophia Botanica," Intellectual History Review 20, no. 2 (2010): 227-52.

35. "[V]isual differentiation functioned as a type of spatial commonplacing, a method of tagging and positioning words in a way that made them stand out within the textual blocks of the Philosophia's aphorisms." Ibid., 243.

36. Larkin, "The Elusive Oeuvre of Jacques Callot,: 84.

37. Eddy, “Tools for Reordering," 227-52.

38. Ibid., 250.

39. Dániel Margócsy, "'Refer to Folio and Number': Encyclopedias, the Exchange of Curiosities, and Practices of Identification before Linnaeus," Journal of the History of Ideas 71, no. 1 (2010): 63-89.

40. Margócsy, "'Refer to Folio and Number,'” 66.

41. Larkin, "The Elusive Oeuvre of Jacques Callot," 165.

42. Margócsy, "'Refer to Folio and Number,"' 70.

43. See discussion of the aesthetic economy of conchologies in Bettina Dietz, "Mobile Objects: The Space of Shells in Eighteenth-Century France," British Journal for the History of Science 39, no. 3 (2006): 363-82.

44. Edme-François Gersaint, Catalogue raisonné de coquilles et autres curiosités naturelles (Paris: Chez Flahault [et Chez] Prault Fils, 1736). See also Dietz, "Mobile Objects," 370; McClelland, "Watteau's Dealer," 445.

45. Martha Langford, "Suspended Conversations: Private Photographic Albums in the Public Collection of the McCord Museum of Canadian History" (PhD diss., McGill University, 1997), 13.

46. Ibid., 15.

47. Ibid., 16.

48. George Lorenzo and Charles Dziuban, "Ensuring the Net Generation is Net Savvy," http:/ / net.educause.edu/ir/ library/pdf/ELI3006.pdf; Ian Rowlands, David Nicholas, Peter Williams, Paul Huntington, and Maggie Fieldhouse, "The Google Generation: The Information Behaviour of the Researcher of the Future," Aslib Proceedings: New Information Perspectives 60, no.4 (2008): 290-310; Mary M. Somerville and Lydia Collins, "Collaborative Design: A Learner-Centered Library Planning Approach," The Electronic Library 26, no. 6 (2008): 803-20.

49. Anders Ekström, Solveig Jülich, Frans Lundgren, and Per Wisselgren, "Participatory Media in Historical Perspective: An Introduction," in History of Participatory Media: Politics and Publics, 1750-2000, eds. Anders Ekström, Solveig Jülich, Frans Lundgren, and Per Wisselgren (New York; London: Routledge, 2011), 1.

50. Ibid., 5 .
51. Joel Postman, SocialCorp: Social Media Goes Corporate (New York: New Riders, 2009).

52. Lisa Gitelman, "Daniel Ellsberg and the Lost Idea of the Photocopy," in Ekström, History of Participatory Media, 114.

53. Bodil Axelsson, "History on the Web: Museums, Digital Media, and Participation," in Ekström, History of Participatory Media, 164.

54. Denis Diderot in Andrew McClelland, "Watteau's Dealer: Gersaint and the Making of Art in Eighteenth-Century Paris," The Art Bulletin 78, no. 3 (1996): 446.

55. David M. Nichols et al., "DEBORA: Developing an Interface to Support Collaboration in a Digital Library," in José Borbinha and Thomas Baker, Proceedings of the Fourth European Conference on Research and Advanced Technology for Digital Libraries (Lisbon, Portugal: Springer, 2000), 240.

56. Gloria Leckie and John Buschman, "Introduction," in Leckie, Critical Theory for Library and Information Science, xiii.

57. Jonathan Foster, "Understanding Interaction in Information Seeking and Use as a Discourse: A Dialogic Approach," Journal of Documentation 65, no. 1 (2009): 83-105.

58. Frances Bell, "Network Theories for TechnologyEnabled Learning and Social Change: Connectivism and Actor Network Theory," http:/ /www.lancs.ac.uk/fss/organisations / netlc/past/nlc2010/abstracts/PDFs/Bell.pdf; Roberta Lamb and Rob Kling, "Reconceptualizing Users as Social Actors in Information Systems Research," MLS Quarterly 27, no. 2 (2003): 197-236; Bruno Latour, We Have Never Been Modern (Cambridge, MA: Harvard University Press, 1993).

59. Peter Checkland and John Poulter, Learning for Action: A Short Definitive Account of Soft Systems Methodology and its Uses for Practitioners, Teachers and Students (Chichester, Eng.: John Wiley and Sons, 2006); Jeremy Rose, "Soft Systems Methodology as a Social Science Research Tool," Systems Research and Behavioral Science 14, no.4 (1997): 249-58.

60. "E-phemeral curating" transfers exhibition maker Jen Hoffmann's notion of "ephemeral curating" to the digital realm. Jens Hoffmann, "Ephemeral Curating," Obsession, Compulsion, Collection: On Objects, Display Culture and Interpretation, ed. Anthony Kiendl (Banff, AB: Banff Centre Press, 2004), 251-69.

61. Izak Benbasat, David K. Goldstein, and Melissa Mead, "The Case Research Strategy in Studies of Information Systems," MIS Quarterly 11, no. 3 (1987): 369-86; A. L. M. Cavaye, "Case Study Research: A Multi-Faceted Research Approach for IS," Information Systems Journal 6 (1996): 227-42.

62. Steve Whittaker and Julia Hirschberg, "The Character, Value, and Management of Personal Paper Archives," ACM Transactions on Computer-Human Interaction 8, no. 2 (2001): 150-70; Lynn A. Wilson, “Building a Conceptual Framework for Creating New Knowledge Through a Virtual Interdisciplinary Environment Process," in e-Research Collaboration: Theory, Techniques and Challenges, eds. Murugan Anandarajan and Asokan Anandarajan (Berlin; London: Springer, 2010), 65-82; Weijia Xu, Maria Esteva, and Suyog Dott Jain, "Visualizing Personal Digital Collections," http:/ / portal.acm.org/citation. cfm?id=1816147\&dl=ACM.

63. N.E. Thing Co., A Portfolio of Piles (Vancouver: Fine Arts Gallery, University of British Columbia, 1968).

64. Paul Longley Arthur, "Virtual Strangers: e-Research and the Humanities," Australian Cultural History 27, no.1 (2009): 
47-59; Jon Rimmer, Claire Warwick, Ann Blandford, Jeremy Gow, and George Buchanan, "An Examination of the Physical and the Digital Qualities of Humanities Research," Information Processing and Management 44 (2008): 1374-92.

65. See Anne Beaulieu and Paul Wouters, "e-Research as Intervention," in e-Research: Transformations in Scholarly Practice, ed. Nicholas W. Jankowski (New York; London: Taylor \& Francis, 2009), 54-69.

66. Ibid., 58.

67. Gary P. Radford, "Flaubert, Foucault, and the Bibliotheque Fantastique: Toward a Postmodern Epistemology for Library Science," Library Trends 46, no. 4 (1998): 616-34.

\section{Additional Sources Consulted}

Bishop, Claire, ed. Participation. London: Whitechapel Gallery; Cambridge, MA: MIT Press, 2006.

Cathro, Warwick. "Collaboration Strategies for Digital Collections: The Australian Experience." http:/ /www. nla.gov.au/openpublish/index.php/nlasp/article/ viewArticle/1433.
Harley, James, and Nick Blismas. "An Anatomy of Collaboration Within the Online Environment." In e-Research Collaboration: Theory, Techniques and Challenges, edited by Murugan Anandarajan and Asokan Anandarajan, 15-34. Berlin: Springer, 2010.

Newhouse, Steven, Jennifer M. Schopf, Andrew Richards, and Malcolm Atkinson. "Study of User Priorities for e-Infrastructure for e-Research (SUPER)." http:/ / www. nesc.ac.uk/technical_papers/UKeS-2007-01.pdf.

Sánchez-Alonso, Salvador, Miguel-Ángel Sicilia, Elena GarcíaBarriocanal, Carmen Pagés-Arévalo, Leonardo Lezcano. "Social Models in Open Learning Object Repositories: A Simulation Approach for Sustainable Collections." Simulation Modelling Practice Theory 19, no.1 (2011): 110-20.

Schroeder, Ralph, and Matthijs den Besten. "Literary Sleuths Online: e-Research Collaboration on the Pynchon Wiki." Information, Communication \& Society 11, no. 2 (2008): 167-87.

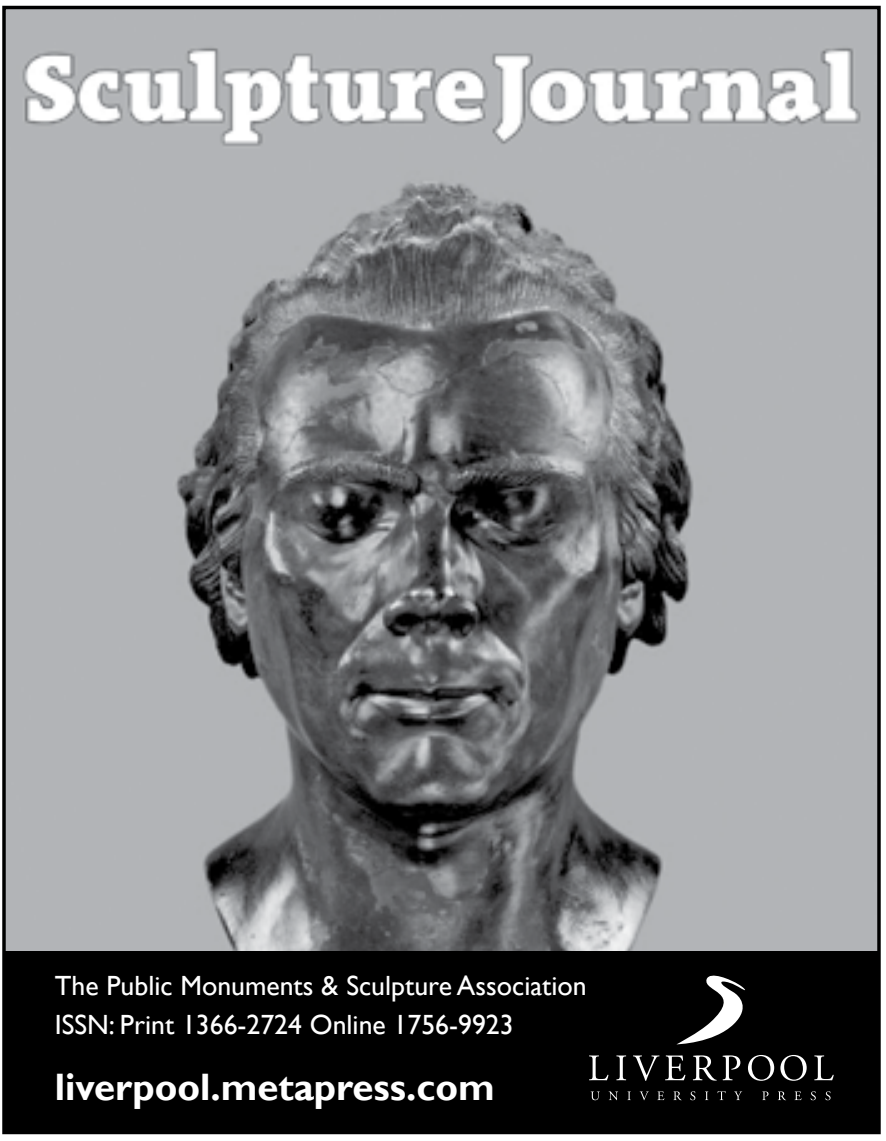

